Pleione 12(1): 143 - 146. 2018.

ISSN: 0973-9467

(C) East Himalayan Society for Spermatophyte Taxonomy

doi:10.26679/Pleione.12.1.2018.143-146

\title{
Tradescantia fluminensis Vell. (Commelinaceae) : A new record of naturalization in India from West Bengal
}

\author{
Suman Nirola ${ }^{2}$ and A. P. Das ${ }^{1}$ \\ Taxonomy \& Environmental Biology Laboratory, Department of Botany, University of North Bengal, \\ Siliguri 734013, WB, India \\ ${ }^{1}$ Present address: Department of Botany, Rajiv Gandhi University, Rono Hills, Doimukh 791112, \\ Arunachal Pradesh, India. apdas.nbu@gmail.com \\ ${ }^{2}$ Corresponding author, e-mail: sunakhari.nirola@gmail.com
}

[Received 29.05.2018; Revised 23.06.2018; Accepted 26.06.2018; Published 30.06.2018]

\begin{abstract}
The article reports the occurrence of Tradescantia fluminensis Vell. (Commelinaceae) for the first time from Darjeeling District of West Bengal, in natural habitat. This forms the first report of its naturalization in India. Detailed description, occurrence, distribution, flowering and fruiting season and illustration are provided in this paper for its easy recognition.
\end{abstract}

Key words: Tradescantia fluminensis, Commelinaceae, new record, India

\section{INTRODUCTION}

Naturalization of introduced exotic plants to a remote location is a common phenomenon. Plants are often carried to remote areas outside their natural range of distribution, intentionally or unintentionally where they may sometime escape, acclimatize and then gradually naturalized (Maiti \& Guha Bakshi 1981; Das \& Chanda 1986; Bhujel \& Das 1996; Das 2002). Recently Khuroo et al. (2012) published a detailed account of alien flora of India and discussed their impact.

While exploring the monocotyledonous flora of Darjeeling district of West Bengal (India) we came across a plant in some areas of Lloyd Botanic Garden $(2100 \mathrm{~m})$ and in the Sepoydhura region $(1630 \mathrm{~m})$ growing naturally. The plant was, later on identified as Tradescantia fluminensis Vell. of Commelinaceae. The identification was basically done by matching with the images in https://commons.wikimedia.org/wiki/ File:Tradescantia_fluminensis_(Flowers).jpg and it is also nicely matching with the Type specimen no. K000363270(K).

The genus Tradescantia L. (Commelinaceae) is represented by 75 accepted species and 5 varieties in the world (www.theplantlist.org). In India, c. six cultivated and naturalized species are known to occur (e-floraofindia), and three of these are reported from the district of Darjeeling (West Bengal) (Nirola 2015). Two of these species, namely Tradescantia pallida (Rose) D.R. Hunt and T. virginiana L. are frequently grown in gardens as ornamental, but they often escapes and grow naturally. However, the present species, T. fluminensis, is not seen to grow as ornamental in the locality, but found growing well naturalized and reproducing in many places between Tung $(1600 \mathrm{~m})$ to Darjeeling $(2100 \mathrm{~m})$, that is in subtropical to temperate belt of Darjeeling Himalaya, along the stream sides and in moist shady areas. 

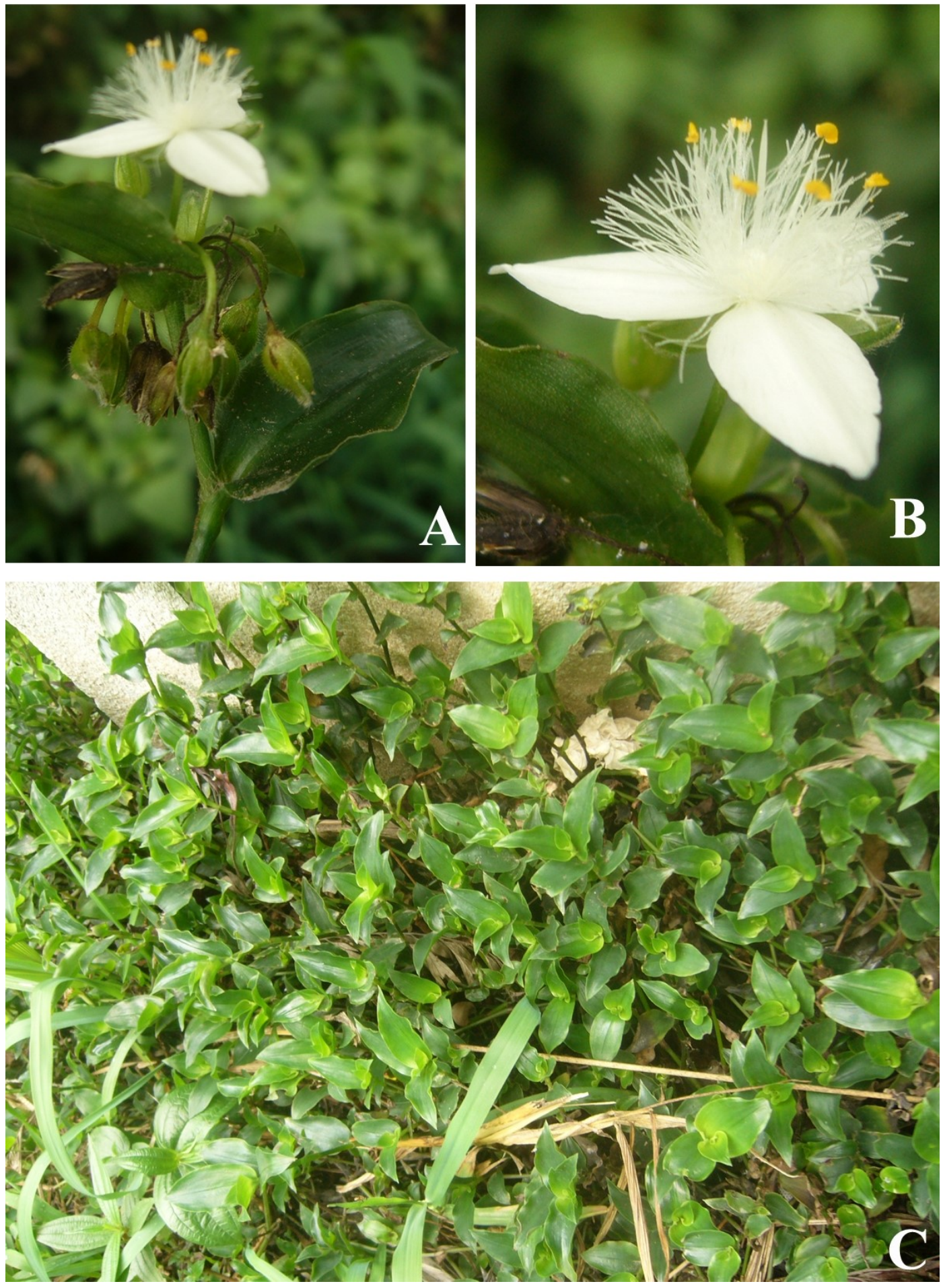

PLATE - I. Tradescantia fluminensis Vell.: A. a flowering twig; B. a flower; C. habit 
The literature survey shows that the naturalization of Tradescantia fluminensis is yet to record from India. So, the species is presented here as a new record of naturalization in Indian vegetation along with its scientific name, a brief description, photographs, phenological data, distribution, specimens examined and preferred habitat structure. For updated nomenclature www.theplantlist.org has been consulted.

Tradescantia fluminensis Vell., F1. Flumin. 3: 140, t. 152. 1829. T. fluminensis var. tenella (Kunth) C.B.Clarke, Monogr. Phan. 3: 295. 1881. T. tenella Kunth, Enum. Pl. 4: 83. 1843. T. mundula Kunth, Enum. P1. 4: 83. 1843. (Commelinaceae) [PLATE - I]

Type: Brazil, Sellow d1286 [Kew image: K000363270]

Small perennial herb. Stems much branched, prostrate and forming dense mats or colonies, rooting from lower nodes. Leaves sessile, alternate; sheath glabrous, $5-9 \mathrm{~mm}$, long-ciliate along margins and mouth; lamina \pm triangularly ovate-lanceolate, $2.5-5 \times 1-2.2 \mathrm{~cm}$, entire, acute, base rounded, clasping, shiny glaucous green, thick textured, herbaceous, both surfaces glabrous. Terminal inflorescence with clusters of flowers subtended by 2 leaf-like, bracts. Flowers pedicelled, erect, drooping after anthesis; pedicel hairy, $1-2 \mathrm{~cm}$, slender. Sepals 3 , lanceolate, $\pm 5 \times 2 \mathrm{~mm}$, green, herbaceous, hairy on back at least along keels, persistent and enclosing the floral parts before and after anthesis; petals broadly ovate-lanceolate, $5-6 \times$ $2.5-3 \mathrm{~mm}$, acute; stamens 6 , all fertile, sub-equal; filaments with equally long, white, erect beards from base; anthers yellow. Ovary 3-loculed; style white, equaling the beards of stamens. Mature fruits not seen.

Flowering \& Fruiting: April - June.

Exsiccata: Sepoydhura, 1636 m, 2100 m, S. Nirola \& AP. Das 1323, dated 26.04. 2010 (NBU)

Status: Rare in few places

Local Distribution: Lower part of Lloyd Botanic Garden, Tung to Darjeeling; 1600-2300 m.

General Distribution: Native of the New World from southern Canada to northern Argentina, naturalized in Australia, Bermuda, Italy, Japan, Kenya, New Zealand, Portugal, Puerto Rico, Russian Federation, Saint Lucia, South Africa, Swaziland, USA and elsewhere including the present record from India.

Note: Naturalized, a new record of naturalization in India from West Bengal.

\section{LITERATURE CITED}

Bhujel, R.B. \& Das, A.P. 1996. Achimenes longiflora (Gesneriaceae): a new record of naturalisation in India. J. Hill Res. 9(1): $109-111$.

Das, A.P. 2002: Survey of naturalised exotics in the flora of Darjiling Hills, West Bengal, (India). J. Econ. Tax. Bot., 26(1): 31 - 37.

Das, A.P. \& Chanda, S. 1986. Notes on some naturalised exotics in Darjeeling Hills, West Bengal (India). Indian Bot. Rep. 5(2): 144 - 147.

https://commons.wikimedia.org/wiki/File:Tradescantia_fluminensis_(Flowers).jpg

http://apps.kew.org/herbcat/getImage.do?imageBarcode=K000363270

https://sites.google.com/site/efloraofindia/system/app/pages/search?scope=searchsite \&q=Tradescantia 
146 Naturalization of Tradescantia fluminensis in India

Khuroo, A.A.; Reshi, Z.A.; Malik, A.H.; Weber, E.; Rashid, I. \& Das, G.H. 2012. Alien flora of India: taxonomic composition, invasion status and biogeographic affiliations. Biol. Invasions 14(1): 99 - 113.

Maiti, G.G. \& Guha Bakshi, D.N. 1981. Invasion of exotic weeds in West Bengal since 1903: Dicotyledons and Monocotyledons. J. Econ. Tax. Bot. 2: $136-168$.

Nirola, Suman. 2015. Studies on the Monotyledonous Flora of Darjeeling District, West Bengal, India. Ph.D Thesis, North Bengal University, India.

www.theplantlist.org, version 1.1, Royal Botanic Gardens, Kew. [studied on 28 May 2018] 